\title{
Physiological Reactions of Sunflower Plants to Different Spices of Selenium
}

\author{
Farzaneh GAROUSI ${ }^{1 *}$, Béla KOVÁCS ${ }^{1}$, Éva BÓDI ${ }^{1}$, Szilvia VÁRALLYAY ${ }^{1}$, \\ Szilvia VERES ${ }^{2}$ \\ ${ }^{1}$ University of Debrecen, Faculty of Agricultural and Food Sciences and Environmental Management, \\ Institute of Food Science, H-4032 Debrecen Böszörményi str. 138, Hungary \\ ${ }^{2}$ University of Debrecen, Faculty of Agricultural and Food Sciences and Environmental Management, \\ Institute of Crop Sciences, Department of Agricultural Botany, Crop Physiology and Biotechnology, \\ H-4032 Debrecen Böszörményi str. 138, Hungary \\ *Corresponding author: farzaneh@agr.unideb.hu
}

Bulletin USAMV series Agriculture 72(2)/2015

Print ISSN 1843-5246; Electronic ISSN 1843-5386

DOI 10.15835/buasvmcn-agr: 11704

\begin{abstract}
Selenium (Se) is an example of an essential element becoming more and more insufficient in food crops as a result of intensive plant production in many countries. Se is an essential biological micronutrient in diet of animals and humans, and plant foods are important sources of dietary Se. It is an essential constituent of several enzymes in which it is present in the form of the unusual amino acid selenocysteine (SeCys). Then, engineering food crops to accumulate higher levels of Se would provide adequate Se to target population. In this study, two species of soluble inorganic selenium forms, selenite $\left(\mathrm{Se}^{\mathrm{IV}}\right)$ and selenate $\left(\mathrm{Se}^{\mathrm{VI}}\right)$ at different concentrations were investigated on sunflower plants that were growing in nutrient solutions during 3 weeks and at the end of the experiment, amounts of SLA for first and second leaves of sunflower were measured. In accordance with the results that we observed, our regarded Se concentrations in $\mathrm{Se}^{\mathrm{IV}}$ form have not been had positive effect on sunflower plants. Whereas samples that had been treated with $0.3 \mathrm{mg} \cdot \mathrm{L}^{-1} \mathrm{Se}^{\mathrm{VI}}$, had the high SLA amount and for second leaves, this increase was significantly. Although high level of $0.9 \mathrm{mg} \cdot \mathrm{L}^{-1}$ and $3 \mathrm{mg} \cdot \mathrm{L}^{-1} \mathrm{Se}^{\mathrm{VI}}$ had negative affect on growth of the samples that had been treated by them.
\end{abstract}

Keywords: physiological reaction, sodium selenite and selenate, sunflower

\section{INTRODUCTION}

Selenium (Se) is a trace element in the environment which is essential at low concentrations to humans and animals, and toxic at high concentrations (Terry et al., 2000; Sors et al., 2005). It has a very narrow range between dietary deficiency and toxic levels (Fordyce, 2007).

Selenate (Se(VI)) and selenite (Se(IV)) are the dominant forms of Se and mechanisms of plant uptake of Se(VI) and Se(IV) are different (Sors et al., 2005).

Despite substantial literature on Se uptake by plants and crops such as wheat, little consideration has been given to sunflower (Helianthus annuus L.) and to date there have been few publications on Se uptake and assimilation in this plant (Longchamp et al., 2011) and parallel to that, investigation of its effects on sunflower leaves' specific leaf area (SLA).

Specific leaf area (SLA; $\mathrm{cm}_{\text {leaf }}^{2} \mathrm{~g}^{-1}$ leaf $)$ the ratio of leaf area to leaf dry mass is a key ecophysiological parameter influencing leaf physiology, photosynthesis, and whole plant carbon gain and also can be used as a rapid and diagnostic tool.

Thick leaves allows a higher concentration of photosynthetic apparatus per unit leaf area, whereas thinner, but larger leaves, allows a higher light interception (White and Montes, 2005) for 
example fast-growing species develop more leaf area per unit leaf biomass, leading to a higher growth rate (Poorter and Van der Werf, 1998). Since the determination of leaf thickness and density is not straightforward, a relative measure is used, namely, specific leaf area (SLA, leaf area to leaf biomass ratio, $\left[\mathrm{cm}^{2} \cdot \mathrm{g}^{-1}\right]$ ) (Larcher, 2001).

In crop growth simulators, the daily increase of leaf area is often derived from the product of leaf mass increase and SLA, whereas the SLA of already formed and expanded leaves is assumed as conserved. The SLA is influenced by many factors and remarkable efforts have been made to isolate the most important ones, aiming to obtain a robust empirical prediction.

The objective of our study was to expose sunflower plants to Se in both forms of sodium seleniteand sodium selenate as well as investigation of their uptake effects on physiological reaction.

\section{MATERIALS AND METHODS}

Sodium selenite and sodium selenate were obtained from Sigma-Aldrich Ltd. (Poole, UK). Nitric acid (69\% ACS, VWR, Lutter-worth, UK) hydrogen-peroxide (30\%, Suprapure grade), and rhodium (1000 $\mathrm{mg} \mathrm{L}^{-1}$ ) for internal standard were obtained from Fluka (Poole, UK). Selenium (1000 $\mathrm{mg} \mathrm{L}^{-1}$ ) reference solution for ICP-MS calibration was supplied by Scharlau Chemie (Germany).

\section{General plant propagation}

Sunflower plant (Helianthus annuus L. cv. Arena PR) was chosen for our research. Disinfected sunflower seeds were geotropically germinated between moist filter papers at $22^{\circ} \mathrm{C}$. Sunflower seedlings with 1.5 to $2.0 \mathrm{~cm}$ hypocotyl were placed into aerated nutrient solution pots. Sunflower plants were grown in a controlled-climate room under strictly regulated environmental conditions. Relative humidity was maintained between 65-75\%, the light/dark cycle was 16-8 h with a respective $25-20{ }^{\circ} \mathrm{C}$ temperature periodicity, and light intensity was kept at a constant $300 \mathrm{mmol}$ $\mathrm{m}^{-2} \mathrm{~s}^{-1}$ during daytime.

\section{Plant growth in nutrient solution}

The nutrient solution used for plant growth had the following composition: $2.0 \mathrm{mM} \mathrm{Ca}\left(\mathrm{NO}_{3}\right)_{2}$, $0.7 \mathrm{mM} \mathrm{K}_{2} \mathrm{SO}_{4}, 0.5 \mathrm{mM} \mathrm{MgSO}{ }_{4}, 0.1 \mathrm{mM} \mathrm{KH}_{2} \mathrm{PO}_{4}$

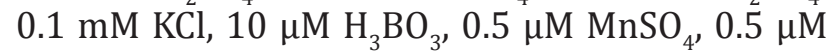
$\mathrm{ZnSO}_{4}$ and $0.2 \mu \mathrm{M} \mathrm{CuSO}_{4}$. Iron was supplied in the form of $10^{-4} \mathrm{M}$ Fe-EDTA, too (Cakmak and Marschner, 1990). Selenium was supplemented to the nutrient solution as two forms of selenite $\left(\mathrm{Na}_{2} \mathrm{SeO}_{3}\right)$ and selenate $\left(\mathrm{Na}_{2} \mathrm{SeO}_{4}\right)$ in five different concentrations as follows: 0 (control), $0.1,0.3,0.9$ and $3 \mathrm{mg} \mathrm{L}^{-1}$. Nutrient solution was changed every 3 days. The experiment harvested after 3 weeks from planting, when the third leaf of the control treatment had completely grown and seedlings had approximately 30-20 cm long shoots and roots, respectively. Experiments were carried out in triplicates (three pots), where every pot had four seedlings.

\section{SLA Measurements}

From each plant, firstand second mature, intact and erect leaves were sampled for determination of the specific leaf area (SLA). From each leaf, 5 leaf discs with a fixed surface area were punched out with a perforator. The samples were collected at both sides of the main midrib, and subsequently dried at $60^{\circ} \mathrm{C}$ for at least 24 hrs till constant weight. The dry weight of all 5 leaf discs together was determined by an electronic balance with an accuracy of 0.001g (OHAUS, Swiss). Finally, SLA $\left(\mathrm{cm}^{2} \cdot \mathrm{g}^{-1}\right)$ of each leaf was calculated by dividing leaf area by corresponding leaf dry weight.

\section{Plant sampling}

At the end of the experiment, shoots were separated from roots and weighted immediately. Plant parts were dried at $70^{\circ} \mathrm{C}$ until constant mass was achieved, then cooled to room temperature and weighed using an analytical scale (OHAUS, Swiss). Dried samples $(0.01,0.5$ or $1 \mathrm{~g}$, depending on our samples' amount) were homogenized and digested by $\mathrm{HNO}_{3}-\mathrm{H}_{2} \mathrm{O}_{2}$ treatment (Kovács et al., 1996). Briefly, samples were kept in 1,5 or $10 \mathrm{~mL}$ concentrated $\mathrm{HNO}_{3}$ overnight, then heated to 60 ${ }^{\circ} \mathrm{C}$ for $45 \mathrm{~min}$ in a LABOR MIM OE 718/A block digestion apparatus. Following the first digestion step, $0.3,1.5$ or $3 \mathrm{ml}$ from $\mathrm{H}_{2} \mathrm{O}_{2}(30 \%)$ were added to the samples and digestion was continued at 120 ${ }^{\circ} \mathrm{C}$ for another $90 \mathrm{~min}$. After cooling the samples at room temperature, volume was adjusted to 5, 25 or $50 \mathrm{ml}$ with deionized water. Samples were then mixed by shaking and filtered through FILTRAK 388 filters.

\section{Quantification of selenium}

Total selenium content was measured on X-Series II (Thermo Fisher Scientific) inductively coupled plasma mass spectrometer (ICP-QMS) equipped with Hexapole Collision Cell Technology (CCT). For quantification of selenium content, 1 $\mathrm{ml}$ of digested sample was diluted to $5 \mathrm{~mL}$ by the 
addition of $3.9 \mathrm{ml}$ water and $0.1 \mathrm{ml} 5 \mathrm{mg}$ rhodium $\mathrm{L}^{-1}$ solution as an internal standard.

The collision/reaction gas was $7 \%$ hydrogen $93 \%$ helium to a flow rate of $6 \mathrm{ml} \mathrm{min}^{-1}$. The sample introduction system consisted of a Meinhard type concentric nebulizer interfaced with a quartz conical spray chamber with impact bead cooled down to $2^{\circ} \mathrm{C}$ by Peltier chiller. Nickel sampler and skimmer cones were used with $1.0 \mathrm{~mm}$ and $0.7 \mathrm{~mm}$ orifice ID, respectively. The sample solutions were pumped at a rate of $0.5 \mathrm{ml} \mathrm{min} \mathrm{m}^{-1}$ by a peristaltic pump from tubes arranged on a CETAC ASX 520 Model auto sampler (CETAC, Omaha, Nebraska, USA). The instrument was controlled usingPlasma Lab (ver. 2.5.10.319, Thermo Fisher Scientific, (Bremen, Germany) software.

The system operation e.g. ion lens voltage, torch position etc.were daily optimized with a multi-element standard solution (Thermo Fisher Scientific, Bremen, Germany) (10 $\left.\mathrm{g} \mathrm{L} \mathrm{L}^{-1}\right)$ according to the standard daily optimization procedure recommended by the manufacturer. Optimization was performed with respect to the maximum ion intensity reaching $>400,000$ integrated counts per second for cobalt and uranium, and $>800,000$ for indium. The oxides and doubly charged ion formation were minimized by monitoring the ${ }^{156} \mathrm{CeO}^{+} /{ }^{140} \mathrm{Ce}^{+}$and ${ }^{138} \mathrm{Ba}^{2+} /{ }^{138} \mathrm{Ba}^{+;}$ratios which were kept below $1 \%$. The ions were detected with a secondary electron multiplier operating in dual mode (pulse counting or analogue mode). Typical instrument settings were, RF power $1.4 \mathrm{~kW}$, plasma gas flow rate $14.0 \mathrm{~L} \mathrm{~min}^{-1}$, auxiliary gas flow rate $1.00 \mathrm{~L} \mathrm{~min}^{-1}$ and nebulizer gas flow rate of $0.90 \mathrm{~L} \mathrm{~min}^{-1}$. Signals were measured using 100 ms dwell time and 9 sweeps for all isotopes as a main run with 3 replications.

The samples were analyzed at $m / z 77,78$, 80 for selenium and $m / z 103$ for rhodium. The range of internal calibration solutions (from 0.5 $\mu \mathrm{g} \mathrm{L} \mathrm{L}^{-1}$ to $20 \mathrm{mg} \mathrm{L}^{-1}$ ) covered the concentration of all analyzed samples. The calibration curves' $2^{\text {nd }}$ order functions were fitted and the correlation coefficients obtained were always higher than 0.995.

\section{Statistical analysis}

All data were statistically analyzed using SPSS 19.0 software (2010), and the mean values of each treatment group were subjected to multiple comparisons analysis using the One-Way ANOVA and a significance level of $\mathrm{p}<0.05$.

Significant differences in the mean value of each treatment group are indicated by different lowercase letters based on the Duncan test ( $p<$ $0.05, \mathrm{n}=3$ ).

\section{RESULTS AND DISCUSSION Chemistry}

During this work, $\mathrm{pH}$ was around 7. According to Fig. 1 that illustrates the various stable forms

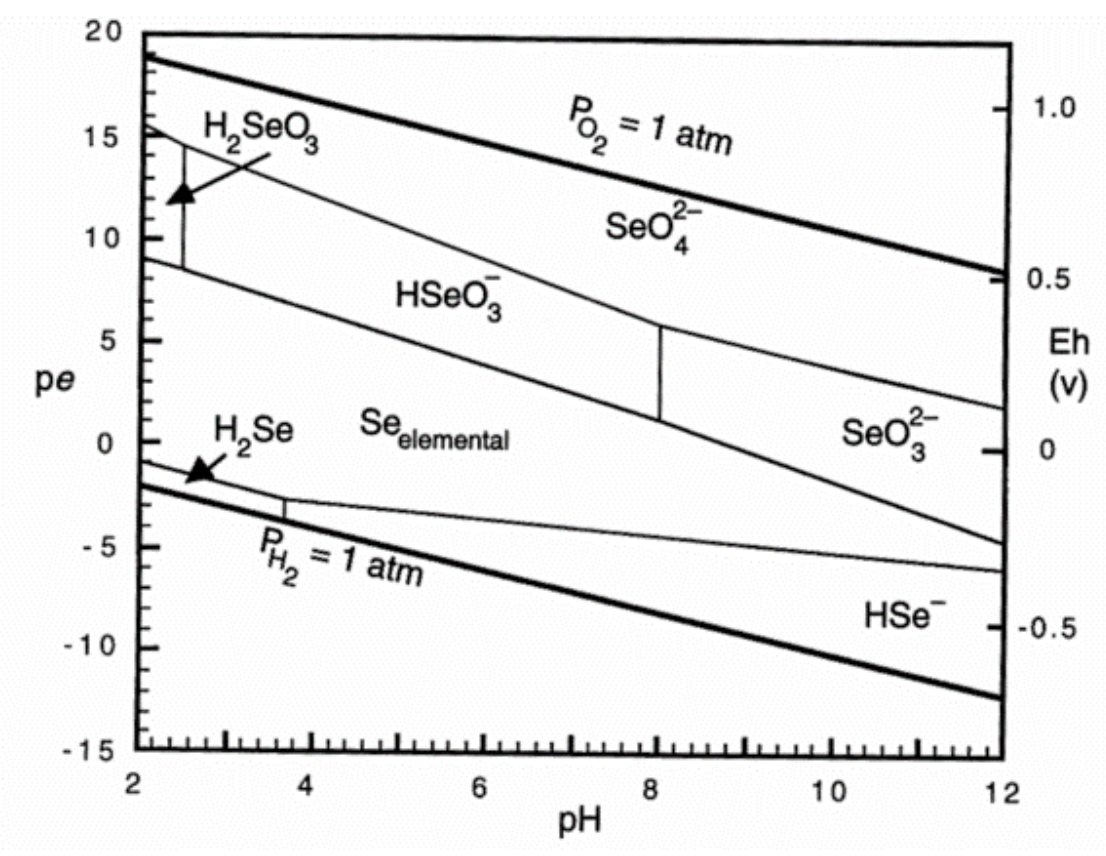

Fig. 1. pE-pH diagram for the Se-O-H system at $298 \mathrm{~K}$ 
of inorganic selenium under different $\mathrm{pH}$ and redox potential conditions (E), Se(VI) that is the fully oxidized Se form, presented in the solution as selenate $\left(\mathrm{SeO}^{2-}\right)$, with a pKa value estimated of $1.8 \pm 0.1$, whereas Selenite presented as biselenite $\left(\mathrm{HSeO}^{3-}\right)$ with a corresponding $\mathrm{pKa}$ value of $8.54 \pm$ 0.04 (Seby et al. 2001).

Se uptake effects on fresh and dry mass of sunflower shoots and roots

The Se physiological reaction, depending on its chemical form, was designated on the basis of fresh mass (FM) and dry mass (DM) of the plant's shoots and roots.

The FM and DM of plant organs decreased, as the $\mathrm{Se}^{\mathrm{IV}}$ concentrations further increased (Tab 1.).

Tab. 2. shows changes of FM and DM of sunflower shoots and roots by increasing the application of $\mathrm{Se}^{\mathrm{VI}}$. Samples treated with 0.9 and $3 \mathrm{mg} \mathrm{L}^{-1} \mathrm{Se}^{\mathrm{VI}}$, had decreasing FM and DM process.

It was found that the Se physiological reaction in the selenite samples, can make lower biomasses than selenate at different concentrations. But fresh and dry biomasses of both, decreased when their concentrations in the growth medium reached 3 $\mathrm{mg} \mathrm{L^{-1 }}$.
This mechanisms of Se, have been discussed extensively in the literature (Terry et al., 2000 and references therein), and our results are in the conformity with that.

\section{$\mathrm{Se}^{\mathrm{IV}}$ uptake effects on first leaves' SLA}

Fig. 2. displays SLA measurements in sunflower at different concentrations of $\mathrm{Se}^{\mathrm{IV}}$ for first leaves. According to our calculation, there was not any significant difference between the treatments although control and $3 \mathrm{mg} . \mathrm{L}^{-1} \mathrm{Se}^{\mathrm{IV}}$ samples had the most and least amounts respectively.

\section{$\mathrm{Se}^{\mathrm{IV}}$ uptake effects on second leaves' SLA}

Fig. 3. displays SLA measurements in sunflower at different concentrations of $\mathrm{Se}^{\mathrm{IV}}$ for second leaves. According to our calculation, there was significant difference between all the samples with $3 \mathrm{mg} \cdot \mathrm{L}^{-1}$.

These results show applying our different regarded $\mathrm{Se}^{\mathrm{IV}}$ concentrations, have not had positive effect on sunflower plants.

\section{$\mathrm{Se}^{\mathrm{VI}}$ uptake effects on first leaves' SLA}

Fig. 4. displays SLA measurements in sunflower at different concentrations of $\mathrm{Se}^{\mathrm{VI}}$ for first leaves. According to our calculation, there were significant diferences between different

Tab. 1. Se $\mathrm{I}^{\mathrm{IV}}$ uptake effect on fresh mass (FM) and dry mass (DM) of sunflower shoot and roots. Significant differences in the mean value of each treatment group are indicated by different lowercase letter based on Duncan test $(p<0.05, \mathrm{n}=3 \pm$ s.e. $)$.

\begin{tabular}{ccccc}
\hline & & shoots & roots \\
\hline Applied $S e^{I V}\left[m g L^{-1}\right]$ & $F M[g]$ & $D M[g]$ & $F M[g]$ & $D M[g]$ \\
\hline $\mathbf{0}$ & $12.1986 \pm 1.7242^{\mathrm{ab}}$ & $0.8488 \pm 0.1815^{\mathrm{a}}$ & $4.7637 \pm 0.7376^{\mathrm{abc}}$ & $0.1587 \pm 0.0263^{\mathrm{a}}$ \\
\hline $\mathbf{0 . 1}$ & $10.6105 \pm 1.8680^{\mathrm{abc}}$ & $0.7345 \pm 0.1945^{\mathrm{a}}$ & $5.4821 \pm 1.6512^{\mathrm{abc}}$ & $0.1769 \pm 0.0581^{\mathrm{a}}$ \\
\hline $\mathbf{0 . 3}$ & $9.3628 \pm 1.1604^{\mathrm{bc}}$ & $0.6527 \pm 0.1537^{\mathrm{a}}$ & $6.2958 \pm 2.1912^{\mathrm{ab}}$ & $0.2158 \pm 0.0770^{\mathrm{a}}$ \\
\hline $\mathbf{0 . 9}$ & $4.9683 \pm 0.5853^{\mathrm{d}}$ & $0.3956 \pm 0.0665^{\mathrm{b}}$ & $3.2010 \pm 1.5679^{\mathrm{cd}}$ & $0.1381 \pm 0.0590^{\mathrm{a}}$ \\
\hline $\mathbf{3}$ & $1.3074 \pm 0.2365^{\mathrm{e}}$ & $0.1368 \pm 0.0285^{\mathrm{c}}$ & $1.5911 \pm 0.8617^{\mathrm{cd}}$ & $0.0937 \pm 0.0452^{\mathrm{a}}$ \\
\hline
\end{tabular}

Tab. 2. Se ${ }^{\mathrm{VI}}$ uptake effect on fresh mass (FM) and dry mass (DM) of sunflower shoots and roots. Significant differences in the mean value of each treatment group are indicated by different lowercase letter based on Duncan test $(p<0.05, \mathrm{n}=3 \pm$ s.e. $)$.

\begin{tabular}{ccccc}
\hline & & shoots & roots \\
\hline Applied $S e^{V l}\left[\mathrm{mg} \mathrm{L}^{-1}\right]$ & $F M[g]$ & $D M[g]$ & $F M[g]$ & $D M[g]$ \\
\hline $\mathbf{0}$ & $12.1986 \pm 1.7242^{\mathrm{ab}}$ & $0.8488 \pm 0.1815^{\mathrm{a}}$ & $4.7637 \pm 0.7376^{\mathrm{c}}$ & $0.1587 \pm 0.0263^{\mathrm{c}}$ \\
\hline $\mathbf{0 . 1}$ & $12.4746 \pm 1.0833^{\mathrm{ab}}$ & $0.9264 \pm 0.1411^{\mathrm{a}}$ & $9.2901 \pm 1.2035^{\mathrm{bc}}$ & $0.2761 \pm 0.0334^{\mathrm{bc}}$ \\
\hline $\mathbf{0 . 3}$ & $14.2597 \pm 2.4180^{\mathrm{ab}}$ & $1.0101 \pm 0.2796^{\mathrm{a}}$ & $8.5743 \pm 2.4788^{\mathrm{bc}}$ & $0.2632 \pm 0.0993^{\mathrm{abc}}$ \\
\hline $\mathbf{0 . 9}$ & $11.8563 \pm 3.9974^{\mathrm{abc}}$ & $0.9019 \pm 0.3471^{\mathrm{a}}$ & $6.9131 \pm 1.6028^{\mathrm{abc}}$ & $0.2394 \pm 0.0667^{\mathrm{abc}}$ \\
\hline $\mathbf{3}$ & $0.4166 \pm 0.0908^{\mathrm{bc}}$ & $0.1080 \pm 0.0286^{\mathrm{b}}$ & $1.0670 \pm 0.2591^{\mathrm{d}}$ & $0.0669 \pm 0.0110^{\mathrm{c}}$ \\
\hline
\end{tabular}




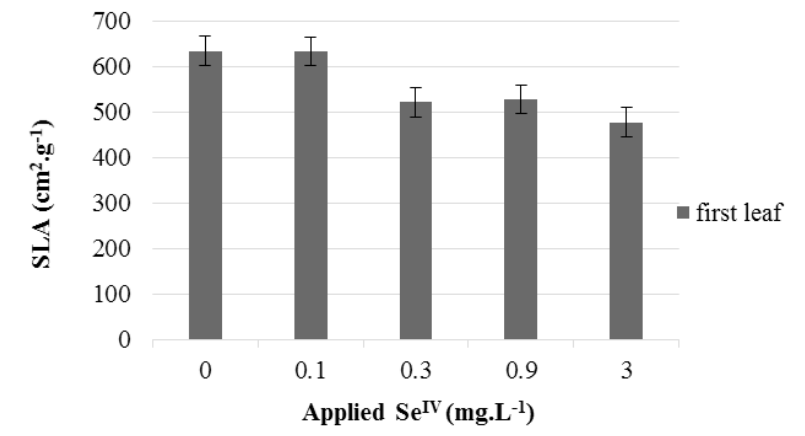

Fig. 2. Se ${ }^{I V}$ uptake effects on first leaves' SLA

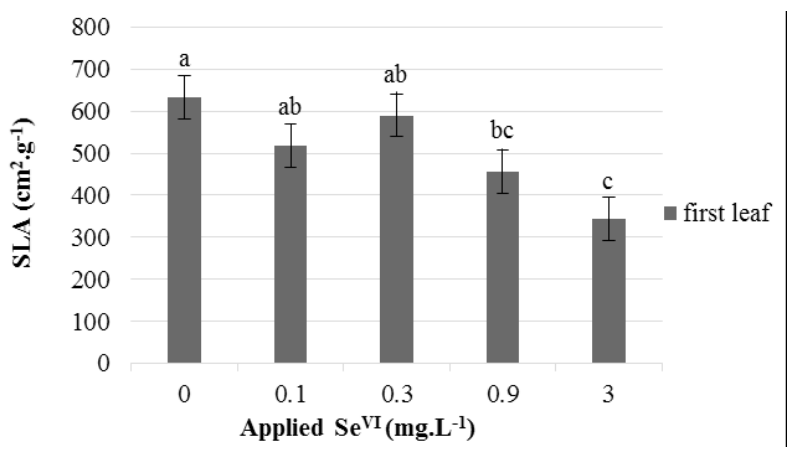

Fig. 4. Se $\mathrm{V}^{\mathrm{VI}}$ uptake effects on first leaves' SLA

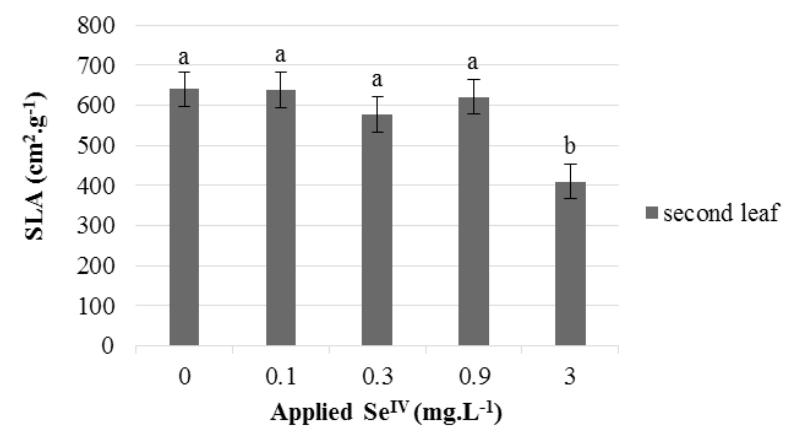

Fig. 3. Se ${ }^{V I}$ uptake effects on second leaves' SLA

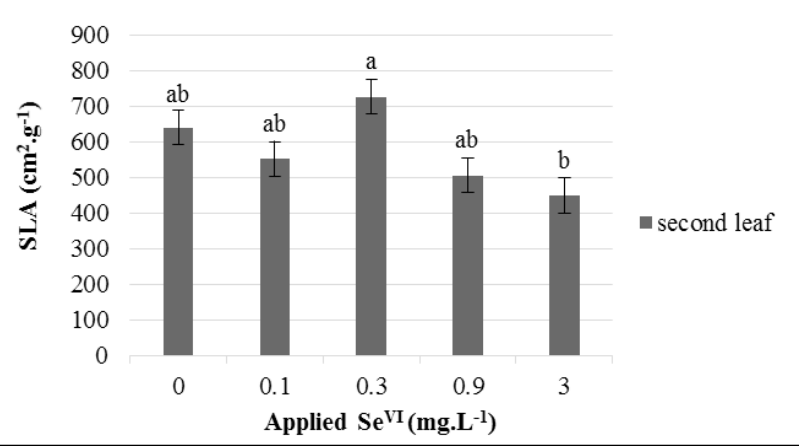

Fig. 5. $\mathrm{Se}^{\mathrm{VI}}$ uptake effects on second leaves' SLA
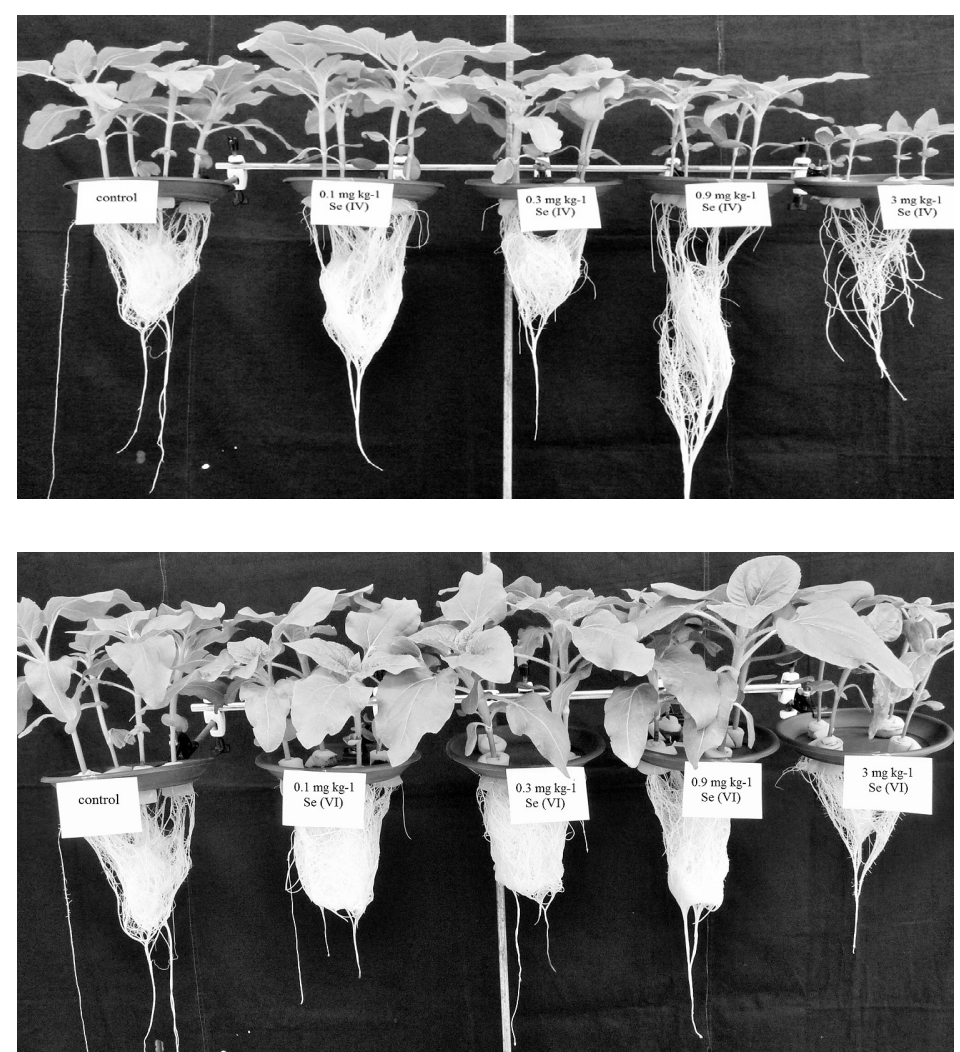

Fig. 6. Different concentrations of $\mathrm{Se}^{\mathrm{IV}}$ and $\mathrm{Se}^{\mathrm{VI}}$ on sunflower, from left: $0,0.1,0.3,0.9$, and $3 \mathrm{mg} . \mathrm{L}^{-1}$ 
concentrations of $\mathrm{Se}^{\mathrm{VI}}$ treatments for first leaves, so that control had the most and $3 \mathrm{mg} \cdot \mathrm{L}^{-1}$ samples had the least amounts of SLA.

\section{$\mathrm{Se}^{\mathrm{VI}}$ uptake effects on second leaves' SLA}

Fig. 5. displays SLA measurements in sunflower at different concentrations of $\mathrm{Se}^{\mathrm{VI}}$ for second leaves. According to our calculation, there were significant diferences between different concentrations of $\mathrm{Se}^{\mathrm{VI}}$ treatments for second leaves, so that $0.3 \mathrm{mg} . \mathrm{L}^{-1} \mathrm{Se}^{\mathrm{VI}}$ had the most and 3 mg. $L^{-1}$ samples had the least amounts of SLA.

\section{CONCLUSION}

Selenium (Se) is a naturally occurring trace element which is toxic at high concentrations, but it is also an essential element for many organisms (Fan et al., 2002) and due to the high solubility of selenite and selenate, these forms are more available to plants (Carvalho and Martin, 2001).

In this work, $0.3 \mathrm{mg} . \mathrm{L}^{-1} \mathrm{Se}^{\mathrm{VI}}$, had the high SLA amount and for second leaves, this increase was significantly. Although high level of $0.9 \mathrm{mg} . \mathrm{L}^{-1}$ and $3 \mathrm{mg} . \mathrm{L}^{-1} \mathrm{Se}^{\mathrm{VI}}$ had negative affect on growth of the samples that had been treated by them. So that, the results for fresh and dry weight of sunflower shoots and roots confirm it, too.

Acknowledgments. The authors are very grateful the cooperation of Faculty of Agricultural and Food Sciences and Environmental Management, Institute of Crop Sciences, Department of Agricultural Botany, Crop Physiology and Biotechnology in Debrecen University.

\section{REFERENCES}

1. Cakmak I, Marschner H (1990). Decrease in nitrate uptake and increase in proton release in zinc deficient cotton, sunflower and buckwheat plants. Plant and Soil 129: 261-268.

2. Carvalho KM, Martin DF (2001). Removal of aqueous selenium by four aquatic plants. Journal of Aquatic Plant Management 39: 33-36.

3. Fan TWM, Teh SJ, Hinton DE, Higashi RM (2002). Selenium biotransformations into proteinaceous forms by foodweb organisms of selenium-laden drainage waters in California. Aquatic Toxicology 57: 65-84.

4. Fordyce F (2007). Selenium geochemistry and health. Ambio 36: 95-98.

5. Kovács B, Győri Z, Prokisch J, Loch J, Dániel P (1996). A study of plant sample preparation and inductively coupled plasma emission spectrometry parameters. Commun Soil Sci Plant Anal 27 (5-8): 1177国1198.

6. Larcher W (2001). Physiological Plant Ecology: Ecophysiology and Stress Physiology of Functional Groups. Springer, Germany p. 513.

7. Longchamp M, Angeli N, Castrec-Rouelle M (2011). Uptake of selenate and/or selenite in hydroponically grown maize plants and interaction with some essential elements (calcium, magnesium, zinc, iron, manganese, and copper). $2^{\text {th }}$ Conf. Selenium: Global perspectives of impacts on humans, animals and the environment China, 2011, p. 83.

8. Poorter H, Van der Werf A (1998). Is inherent variation in RGR determined by LAR at low irradiance and by NAR at high irradiance. A review of herbaceous species. Inherent Variation in Plant Growth 309-336.

9. Seby F, Potin-Gautier M, Giffaut E, Borge G, Donard OFX (2001). A critical review of thermodynamic data for seleniumspecies at 25 degrees C. Chem. Geol 171: 173194.

10. Sors TG, Ellis DR, Salt DE (2005). Selenium uptake, translocation, assimilation and metabolic fate in plants. Photosynth. Res 86: 373-389.

11. Terry N, Zayed AM, de Souza MP, Tarun AS (2000). Selenium in higher plants. Annu Rev Plant Physiol Plant Mol Biol 51:401-432.

12. White JW, Montes RC (2005). Variation in parameters related to leaf thickness in common bean (Phaseolus vulgaris L.). Field Crop Res 91(1): 7-21. 